\title{
UTILIZATION OF ZEOLITS FOR WATER FILING
}

\author{
Sajaratud Dur \\ Program Studi Matematika FST \\ Universitas Islam Negeri Sumatera Utara \\ sajaratuddur@uinsu.ac.id
}

\begin{abstract}
This study aims to obtain zeolite powder from Sarulla natural zeolite as an adsorbent, particle size of zeolite powder, and water analysis before and after water purification. The benefit is to increase the benefits of zeolite to a higher economic value.The method used is the grinding mill method to smooth the zeolite chunks. Whereas the water purification process uses a screening process.The results of this study were zeolite produced at 200 mesh or 74 microns, and the purification was successfully carried out.The conclusion of this study is that zeolite powder obtained from Sarulla natural zeolite as an adsorbent, obtained zeolite particles namely 200 mesh or 74 microns, and the water purification process was successfully carried out.
\end{abstract}

\section{Keyword: Zeolits, Water Filling}

Abstrak. Penelitian ini bertujuan untuk mendapatkan serbuk zeolit dari Sarulla zeolit alam sebagai adsorben, ukuran partikel serbuk zeolit, dan analisis air sebelum dan sesudah pemurnian air. Manfaatnya adalah meningkatkan manfaat zeolit ke nilai ekonomi yang lebih tinggi. Metode yang digunakan adalah metode gilingan untuk menghaluskan potongan zeolit. Sedangkan proses penjernihan air menggunakan proses penyaringan. Hasil penelitian ini adalah zeolit yang diproduksi pada 200 mesh atau 74 mikron, dan pemurnian itu berhasil dilakukan. , diperoleh partikel zeolit yaitu 200 mesh atau 74 mikron, dan proses pemurnian air berhasil dilakukan.

Kata Kunci : Zeolit. Penjernihan, Air

\section{PENDAHULUAN}

Pemanfaatan bahan baku dari alam daripada bahan baku sintetis merupakan isu lingkungan yang sudah lama berkembang. Hal ini berkaitan dengan beberapa kelebihan bahan baku alam seperti lebih ramah lingkungan dan potensinya yang cukup banyak dan dapat diperbaharui.

Ukuran partikel mempunyai hubungan secara langsung dengan permukaan per gram pengisi. Semakin kecil ukuran partikel semakin tinggi interaksi antara pengisi dan matriks polimer (Ismail, 2000). Luas permukaan dapat ditingkatkan dengan keberadaan permukaaan yang berpori pada permukaan pengisi sehingga polimer mampu menembus masuk ke dalam permukaan yang berpori saat proses pencampuran (Kohls dan Beaucage, 2002). 
Permukaan yang memiliki pori dan bentuk yang tidak seragam dapat meningkatkan daya ikat (Hanafi, dkk. 2005).

Data Kementerian Pertambangan dan Energi Propinsi Sumatera Utara tahun 2003 bahwa komposisi zeolit alam dari Kecamatan Sarulla Kabupaten Tapanuli Utara Sumatera Utara adalah $60,16 \% \mathrm{SiO}_{2}, 4,20 \% \mathrm{Fe}_{2} \mathrm{O}_{3}$, dan $14,25 \%$ $\mathrm{Al}_{2} \mathrm{O}_{3}$. Harahap (2006) menemukan deposit zeolit alam sebanyak 3.340.000 ton persis di pinggir jalan lintas antara Sarulla - Sipirok. Aini dan Indriati (2007) menggunakan zeolit sebagai pengisi kertas untuk menggantikan kaolin. Chen, dkk. (2011) menambahkan zeolit pada sisi luar karton bergelombang sehingga karton lebih tahan terhadap kelembaban dan membantu sisi dalam bertahan lebih lama. Zeolit adalah nama umum untuk kelompok zeolit yang mana kristal- kristalnya merupakan aluminosilikat logam alkali dan alkali tanah yang mengandung air. Zeolit adalah zat berpori dengan pori-pori berskala nanometer.

Tujuan dari penelitian ini adalah sebagai berikut:

1. Mendapatkan zeolit dari zeolit alam Sarulla sebagai adsorben.

2. Mendapatkan ukuran partikel zeolit, analisa air sebelum dan sesudah penjernihan air.

Manfaat dari penelitian ini adalah:

1. Zeolit meningkat nilainya dari segi ekonomis.

2. Air jernih sebagai sumber air bersih dalam kegiatan sehari-hari.

\section{TINJAUAN PUSTAKA}

\section{Zeolit}

Zeolit yang berarti batu mendidih, diberikan oleh seorang ahli mineralogi Swedia FAF Crostedt pada mineral yang ditemukannya pada tahun 1756 yang dapat menghamburkan uap seperti air mendidih jika dipanaskan pada suhu $100^{\circ} \mathrm{C}$ sampai dengan $350^{\circ} \mathrm{C}$. Sejak saat itu telah ditemukan 50 jenis zeolit alam dan 150 jenis zeolit buatan. Zeolit adalah polimer anorganik yang tersusun dari unit berulang terkecil berupa tetrahedra $\mathrm{SiO}_{4}$ dan $\mathrm{AlO}_{4}$. Ikatan antar tetrahedra terbentuk dengan pemakaian bersama satu atom oksigen oleh dua tetrahedra sehingga setiap tetrahedra akan berikatan dengan 4 tetrahedra lainnya. Polimer yang terbentuk adalah jaringan tetrahedra tiga dimensi berupa kristal-kristal yang didalamnya terdapat saluran-saluran pori dan rongga-rongga yang tersusun secara beraturan. Rongga-rongga kristal berupa air bebas dan ada yang terikat dan jika dipanaskan akan terbentuk ruang hampa. Zeolit secara empirik dapat dinyatakan dengan rumus molekul berikut: 


\section{$\mathrm{M}_{2} / \mathrm{n} \mathrm{Al}_{2} \mathrm{O}_{3} \mathrm{XsiO}_{2} \mathrm{YH}_{2} \mathrm{O}$;}

atau jika disesuaikan dengan strukturnya maka dapat dinyatakan sebagai berikut:

$$
\mathrm{Mx}^{\prime} / \mathrm{n}\left[\left(\mathrm{AlO}_{2}\right) \mathrm{x}^{\prime}\left(\mathrm{SiO}_{2}\right) \mathrm{y}^{\prime}\right] . \mathrm{WH}_{2} \mathrm{O}
$$

dengan $\mathrm{M}$ adalah kation penetral alkali atau alkali tanah yang bervalensi $\mathrm{n}$ dan suku yang berada di dalam kurung menyatakan rumus molekul kerangka zeolit, $x$ adalah suatu harga dari 2-10 (Mc.Bain, 1932).

Hampir seluruh endapan zeolit yang ditemukan di Indonesia tersusun oleh mineral klinoptilolit, mordenit atau campuran keduanya, kadang - kadang sedikit mengandung mineral heulandit. Disamping mengandung mineral tersebut zeolit juga mengandung mineral pengotor seperti kwarsa, plagioklas, montmorilonit, pirit, kaolin dan lain - lain. Warna bahan galian zeolit beraneka ragam antara lain hijau, putih kehijauan, putih merah daging, coklat abu - abu kebiruan dan lainnya bergantung dengan kondisi lingkungan yang mempengaruhinya. Zeolit alam merupakan senyawa alumina silikat terhidrasi yang secara fisik dan kimia mempunyai kemampuan sebagai penyerap (adsorpsi), penukar kation dan sebagai katalis. Zeolit sintetik dihasilkan dari beberapa perusahaan seperti Union Carbide, ICI dan Mobil Oil dan lebih dari 100 jenis telah dikenal strukturnya antara lain zeolit A, X, Y, grup ZSM/AlPO 4 (Zeolite Sieving Materials/Aluminium Phosphate) dan bahkan akhir-akhir ini dikenal grup Zeotip, yaitu material seperti zeolit tetapi bukan senyawa alumino-silikat. Kemampuan pertukaran ion zeolit merupakan parameter utama dalam menentukan kualitas zeolit yang akan digunakan, biasanya dikenal sebagai KTK (Kapasitas Tukar Kation). KTK adalah jumlah meq ion logam yang dapat diserap maksimum oleh $1 \mathrm{gr}$ zeolit dalam kondisi setimbang. Kapasitas tukar kation (KTK) dari zeolit bervariasi dari 1,5 sampai 6 meq/g. Nilai KTK zeolit ini banyak tergantung pada jumlah atom Al dalam struktur zeolit, yang jauh lebih tinggi dibandingkan dengan KTK batuan lempung, seperti kaolinit (0,03-015 meq/g), bentonit (0,80-1,50 meq/g) dan vermikulit (1-1,50 meq/g). Kandungan air yang terperangkap dalam rongga zeolit biasanya berkisar antara 10-35\%. Perbandingan antara atom Si dan Al yang bervariasi akan menghasilkan banyak jenis atau spesies zeolit yang terdapat di alam. Sampai saat ini telah ditemukan lebih dari 50 jenis spesies zeolit, namun mineral pembentuk zeolit terbesar ada 9 (sembilan) yaitu analsim, habazit, klinoptilolit, erionit, mordenit, ferrierit, heulandit, laumontit dan filipsit. Pengaruh suhu pada zeolit ditampilkan pada Tabel 2.1.

Tabel 2.1 Stabilitas Zeolit Terhadap Suhu

\begin{tabular}{llc}
\hline Jenis Mineral Zeolit & & Suhu $\left({ }^{0} \mathrm{C}\right)$ \\
\hline Klinoptilolit (kaya ion Ca) & (maks.) & 500 \\
Klinoptilolit (kaya ion K) & (maks.) & 800 \\
Kabazit & & $600-865$ \\
Laumonit & $345-800$ \\
\hline
\end{tabular}




\begin{tabular}{lc}
\hline Mordenit & $800-1000$ \\
Filipsit & $360-400$ \\
\hline
\end{tabular}

Mineral zeolit yang umum dijumpai adalah jenis klinoptilolit dan mordenit (Harahap, 2006). Beberapa jenis zeolit alam yang telah ditemukan berikut rumus molekulnya ditampilkan pada Tabel 2.2.

Tabel 2.2 Rumus Molekul Beberapa Jenis Zeolit

(Mozgawa, dkk., 2011)

\begin{tabular}{|c|c|c|c|}
\hline $\begin{array}{l}\text { Nama } \\
\text { Mineral }\end{array}$ & $\begin{array}{l}\text { Rumus } \\
\text { Molekul }\end{array}$ & $\begin{array}{l}\text { Kode } \\
\text { IUPAC }\end{array}$ & Cincin \\
\hline Analsim & $\mathrm{Na}_{16}\left[\mathrm{Al}_{16} \mathrm{Si}_{32} \mathrm{O}_{96}\right] \cdot 16 \mathrm{H}_{2} \mathrm{O}$ & ANA & $4,6,8$ \\
\hline Filipsit & $\mathrm{K}_{2}(\mathrm{Ca} 0,5, \mathrm{Na})_{4}\left[\mathrm{Al}_{6} \mathrm{Si}_{10} \mathrm{O}_{32}\right] \cdot 12 \mathrm{H}_{2} \mathrm{O}$ & PHI & 4,8 \\
\hline Harmotom & $\mathrm{Ba}(\mathrm{Ca} 0,5, \mathrm{Na})\left[\mathrm{Al}_{5} \mathrm{Si}_{11} \mathrm{O}_{32}\right] \cdot 12 \mathrm{H}_{2} \mathrm{O}$ & PHI & 4,8 \\
\hline Gismondit & $\mathrm{Ca}_{4}\left[\mathrm{Al}_{8} \mathrm{Si}_{8} \mathrm{O}_{32}\right] \cdot 16 \mathrm{H}_{2} \mathrm{O}$ & GIS & 4,8 \\
\hline Loumontit & $\mathrm{Ca}_{4}\left[\mathrm{Al}_{8} \mathrm{Si}_{16} \mathrm{O}_{48}\right] \cdot 16 \mathrm{H}_{2} \mathrm{O}$ & LAU & $4,6,1$ \\
\hline Zeolite A & $\mathrm{Na}_{12}\left[\mathrm{Al}_{24} \mathrm{Si}_{24} \mathrm{O}_{48}\right] \cdot 27 \mathrm{H}_{2} \mathrm{O}$ & LTA & $4,6,8$ \\
\hline Kankrinit & $\mathrm{Na}_{6} \mathrm{Ca}\left[\mathrm{CO}_{3}\left(\mathrm{AlSiO}_{4}\right)_{6}\right] \cdot 2 \mathrm{H}_{2} \mathrm{O}$ & CAN & $4,6,12$ \\
\hline Levin & $\mathrm{NaCa}_{2,5}\left[\mathrm{Al}_{6} \mathrm{Si}_{12} \mathrm{O}_{36}\right] \cdot 18 \mathrm{H}_{2} \mathrm{O}$ & LEV & $4,6,8$ \\
\hline Offretit & $\mathrm{KcaMg}\left[\mathrm{Al}_{5} \mathrm{Si}_{13} \mathrm{O}_{36}\right] \cdot 15 \mathrm{H}_{2} \mathrm{O}$ & OFF & $4,6,8,12$ \\
\hline Kabasit & $\mathrm{Ca}_{2}\left[\mathrm{Al}_{4} \mathrm{Si}_{8} \mathrm{O}_{24}\right] \cdot 12 \mathrm{H}_{2} \mathrm{O}$ & CHA & $4,6,8$ \\
\hline Faujasit & $\mathrm{Na}_{20} \mathrm{Ca}_{12} \mathrm{Mg}_{8}\left[\mathrm{Al}_{60} \mathrm{Si}_{132} \mathrm{O}_{384}\right] \cdot 235 \mathrm{H}_{2} \mathrm{O}$ & FAU & $4,6,12$ \\
\hline Gmelinit & $\mathrm{Na} 8\left[\mathrm{Al}_{8} \mathrm{Si}_{16} \mathrm{O}_{48}\right] \cdot 22 \mathrm{H}_{2} \mathrm{O}$ & GME & $4,6,8,12$ \\
\hline Edingtonit & $\mathrm{Ba}_{2}\left[\mathrm{Al}_{4} \mathrm{Si}_{6} \mathrm{O}_{20}\right] \cdot 8 \mathrm{H}_{2} \mathrm{O}$ & EDI & 4,8 \\
\hline Thomsonit & $\mathrm{Na}_{4} \mathrm{Ca} 8\left[\mathrm{Al}_{20} \mathrm{Si}_{20} \mathrm{O}_{80}\right] .24 \mathrm{H}_{2} \mathrm{O}$ & THO & 4,8 \\
\hline Skolesit & $\mathrm{Ca} 8\left[\mathrm{Al}_{16} \mathrm{Si}_{24} \mathrm{O}_{80}\right] \cdot 24 \mathrm{H}_{2} \mathrm{O}$ & NAT & 4,8 \\
\hline Natrolit & $\mathrm{Na}_{16}\left[\mathrm{Al}_{16} \mathrm{Si}_{24} \mathrm{O}_{80}\right] \cdot 16 \mathrm{H}_{2} \mathrm{O}$ & NAT & 4,8 \\
\hline Brewsterit & $\mathrm{Sr}_{2}\left[\mathrm{Al}_{4} \mathrm{Si}_{12} \mathrm{O}_{32}\right] \cdot 10 \mathrm{H}_{2} \mathrm{O}$ & BRE & $4,5,6,8$ \\
\hline Stilbit & $\mathrm{NaCa}_{4}\left[\mathrm{Al}_{9} \mathrm{Si}_{27} \mathrm{O}_{72}\right] \cdot 30 \mathrm{H}_{2} \mathrm{O}$ & STI & $4,5,6,8,10$ \\
\hline Heulandit & $(\mathrm{K}, \mathrm{Na}) \mathrm{Ca}_{4}\left[\mathrm{Al}_{9} \mathrm{Si}_{27} \mathrm{O}_{72}\right] \cdot 24 \mathrm{H}_{2} \mathrm{O}$ & HEU & $4,5,8,10$ \\
\hline Klinoptilolit & $\left(\mathrm{K}_{2}, \mathrm{Na}_{2}, \mathrm{Ca}\right) 3\left[\mathrm{Al}_{6} \mathrm{Si}_{30} \mathrm{O}_{72}\right] \cdot 20 \mathrm{H}_{2} \mathrm{O}$ & HEU & $4,5,8,10$ \\
\hline
\end{tabular}

Menurut sumber dari Kementerian Pertambangan dan Energi Propinsi Sumatera Utara tahun 2003 bahwa komposisi zeolit alam dari Kecamatan Sarulla Kabupaten Tapanuli Utara Propinsi Sumatera Utara adalah 60,16\% $\mathrm{SiO}_{2}, 4,20 \% \mathrm{Fe}_{2} \mathrm{O}_{3}$, dan $14,25 \% \mathrm{Al}_{2} \mathrm{O}_{3}$.

\section{Sifat-Sifat Zeolit}

Struktur dan komposisi zeolit seperti yang diuraikan secara singkat di atas menjadikan zeolit sebagai padatan yang memiliki sifat-sifat kimia yang unik, diantaranya adalah:

a. Sangat berpori karena kristal zeolit sebenarnya merupakan kerangka yang terbentuk dari jaringan tetrahedra $\mathrm{SiO}_{4}$ dan $\mathrm{AlO}_{4}$. 
b. Pori-porinya berukuran molekul karena pori zeolit terbentuk dari tumpukan cincin beranggotakan 6,8,10 atau 12 tetrahdra.

c. Dapat mempertukarkan kation karena perbedaan muatan $\mathrm{Al}(+3)$ dan $\mathrm{Si}(+4)$ menjadikan atom $\mathrm{Al}$ dalam kerangka kristal bermuatan negatif dan membutuhkan kation penetral. Kation penetral yang bukan menjadi bagian kerangka ini mudah diganti dengan kation lainnya.

d. Dapat diubah menjadi padatan yang bersifat asam karena penggantian kation penetral dengan proton menjadikan zeolit sebagai padatan asam Bronsted.

e. Mudah dimodifikasi karena setiap tetrahedra dapat dikontakkan dengan bahan-bahan pemodifikasi. Modifikasi yang dikenakan pada zeolit diantaranya adalah: pertukaran ion, penggantian inti tetrahedra dengan atom logam lainnya seperti $\mathrm{Ga}, \mathrm{Fe}, \mathrm{B}$, dan $\mathrm{Ti}$, pengendalian keasaman baik jumlah maupun kekuatan pusat asamnya dengan cara mengatur perbandingan Si/Al dalam kerangka kristal.

Selain sifat kimianya, sifat-sifat fisik zeolit adalah:

a. Warna zeolit

Umumnya berwarna putih atau bening jika belum mengalami pengotoran, tetapi dapat berwarna merah daging, merah muda atau kelabu dengan adanya inklusi dari oksidasi atau mineral-mineral asing lainnya;

b. Bentuk kristal zeoli

Secara umum ada 3 macam yaitu berserabut atau berserat, pipih, dan bersegi atau ekuidimensional;

c. Ukuran kristal zeolit

Umumnya lebih dari 2 mikron dan maksimum dapat mencapai 4 inci.

d. Berat jenis zeolit

Berat jenis zeolit relatif rendah rata-rata 2,0 - 2,5.

e. Kekerasan

Ukuran kekerasan pada skala Mohs: 2,5 - 10.

f. Indeks reflaksi

Indeks reflaksi berkisar 1,44 - 1,52.

g. Tidak berkilap (suram atau kabur) kecuali pada beberapa bidang belahan tertentu, ditemukan kilap seperti mutiara (Mc.Bain, 1932).

Zeolit sebagai Penyerap

Kemampuan zeolit sebagai adsorben/penyerap pertama kali diungkap oleh Damour (1840) setelah mengamati bahwa mineral zeolit dapat didehidrasi secara reversibel tanpa menunjukkan perubahan morfologinya. Weigel dan Steinhoff (1925) melaporkan bahwa Kalasit dapat mengadsorpsi secara selektif molekul-molekul besar. Zeolit sebagai penyaring molekul memiliki 
kemampuan memisahkan molekul berdasarkan bentuk dan ukurannya. Adsorben zeolit sebagai penyaring molekul yang sangat penting ialah zeolit sintetis tipe A, tipe $\mathrm{X}$, modernit sintetis, berbagai penukar ion, zeolit alam kabazit, dan mordenit (Mc.Bain, 1932). Dalam susunan kristal zeolit terdapat ruang hampa dengan volume ruang mencapai $50 \AA$ dan garis tengah berkisar

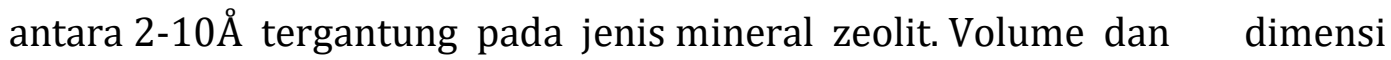
diameter ruang hampa dalam kisi-kisi kristal zeolit merupakan dasar indikasi mineral zeolit bersifat sebagai penyaring molekul. Pada keadaan normal ruang hampa yang terdapat dalam kristal zeolit ditempati oleh molekul air bebas yang membentuk bulatan di sekitar kation. Jika kristal tersebut dipanaskan selama beberapa jam pada temperatur di atas $100^{\circ} \mathrm{C}$ maka molekul air bebas tersebut akan terbang. Begitu pula dengan air hidratnya akan hilang pada pemanasan yang lebih tinggi sehingga mineral zeolit mampu berfungsi sebagai penyerap gas atau cairan. Intensitas zeolit mengadsorpsi suatu bahan tergantung pada kapasitas ruang hampa dan luas permukaan (Dur, 1998).

Permukaan yang memiliki pori dan bentuk yang tidak seragam dapat meningkatkan adhesi (Hanafi, dkk., 2005). Jumlah luas permukaan dapat ditingkatkan dengan keberadaan permukaan yang berpori pada permukaan materi. Polimer dapat menembus masuk ke dalam permukaan yang berpori ketika proses pencampuran (Kohls dan Beaucage, 2002).

Zhai, dkk., (2007) menyatakan bahwa partikel $\mathrm{Al}_{2} \mathrm{O}_{3}$ berukuran nanometer diantarkan ke dalam suatu adesif epoksi untuk meningkatkan kekuatan adesi dari baja terikat yang menggunakan utilitas adesif termodifikasi maupun tanpa modifikasi epoksi. Kekuatan rekat diukur oleh test pull-off adhesion sebagai suatu fungsi dari sejumlah $\mathrm{Al}_{2} \mathrm{O}_{3}$ ukuran nanometer dan ketajaman antar muka. Hasilnya mengindikasikan bahwa kekuatan rekat meningkat secara dramatis oleh penambahan $\mathrm{Al}_{2} \mathrm{O}_{3}$ ukuran nanometer ke dalam adesif epoksi yang dibandingkan dengan adesif epoksi murni. Kekuatan rekat tertinggi terjadi pada saat pemberian 2\% berat $\mathrm{Al} 203$ ukuran nanometer di dalam adesif epoksi, hampir 4 (empat) kali lebih tinggi daripada yang tanpa modifikasi. Sebagaimana kekuatan rekat meningkat, daerah patahan berubah dari interfasial menjadi campuran interfasial dan kohesif.

\section{Penelitian sebelumnya}

Penelitian yang berkaitan sebelumnya diantaranya seperti di bawah ini.

Sajaratud Dur tahun 2016 meneliti nanokristal selulosa dari TKS sebagai bahan penguat adesif dan nanozeolit dari zeolit yang berasal dari Sarulla sebagai penguat adesif. Abdi Maulana tahun 2017 meneliti batu zeolit untuk penjernih air. 


\section{METODE PENELITIAN}

Zeolit alam diperoleh dari Sarulla Tapanuli Utara Sumatera UtaraBahan dan alat yang dipersiapkan secara garis besar adalah bahan dan alat untuk pembuatan partikel zeolit aktif, dan karakterisasi.Prosedur penelitian ada 4 tahapan yaitu tahap penyediaan zeolit, dan penyaringan (filter), penjernihan, dan karakterisasi.

\section{Preparasi dan Karakterisasi Zeolit dari Batu Zeolit Alam}

Batu zeolit alam dihancurkan menggunakan alu dan mortal. Kemudian dihaluskan menggunakan alat Ballmill pada kecepatan 300 rpm selama 30 menit. Diayak menggunakan ayakan 200 mesh lalu disimpan dalam vakum desikator.

\section{Penyaringan Air Sungai Mengunakan Serbuk Zeolit}

Diukur volume air sungai sebanyak $600 \mathrm{ml}$ dan dituang kedalam beaker glass. Ditimbang serat selulosa dan zeolit dengan variasi 2, 8, dan 14 gram. Kemudian air sungai disaring menggunakan kertas saring No.1 dan ditampung di dalam erlenmeyer. Dianalisa kadar logam Fe, Mn, dan $\mathrm{Cu}$ menggunakan alat spektrofotometer serapan atom (SSA).

\section{Pengujian Sampel}

Uji Ukuran Partikel Zeolit:

Particle Size Analyzer Vasco adalah alat untuk mengukur partikel yang berukuran nanometer dalam liquid. Prinsip pengukuran didasarkan pada penghamburan cahaya yang tersebar. Teknologi ini telah dipatenkan dan dikembangkan oleh Institute of France Petroleum (IFP).

\section{HASIL DAN PEMBAHASAN}

\section{Zeolit}

Kandungan zeolit alam telah dikarakterisasi dengan menggunakan difraksi Sinar-X dan dibandingkan dengan hasil karakterisasi zeolit mordenit (MOR) standar. Karakterisasi dengan menggunakan XRD memberikan pola difraksi seperti pada tampilan Gambar 4.1. 


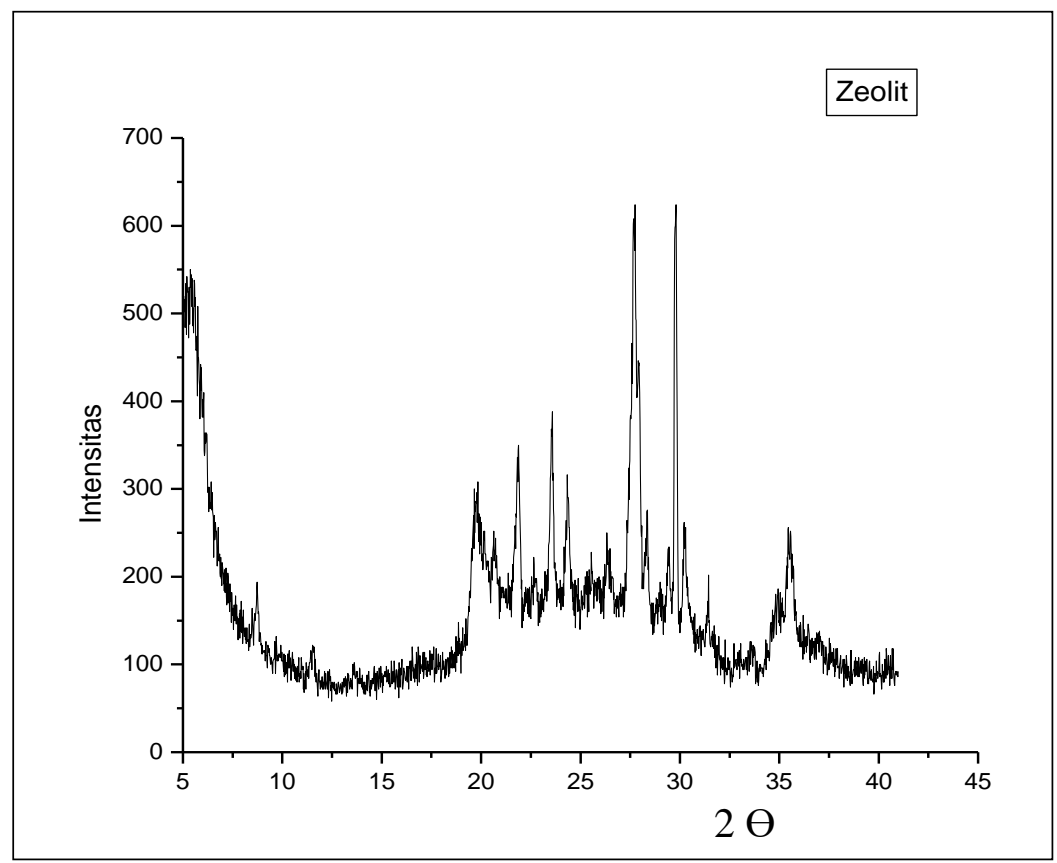

Gambar 4.1 Spektrum Zeolit Alam Menggunakan Difraksi Sinar-X

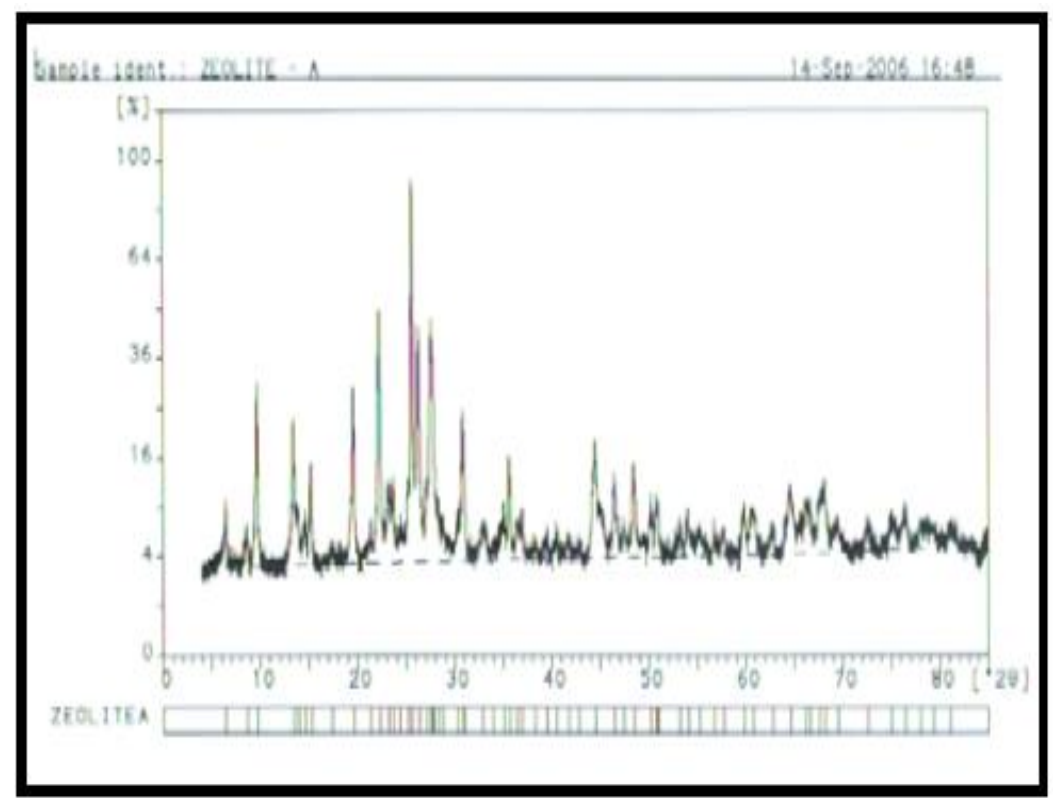

Gambar 4.2 Spektrum Zeolit Mordenit (MOR) Standar Menggunakan Difraksi Sinar-X

Hasil difraktogram dari zeolit alam pada Gambar 4.1 menunjukkan intensitas terbesar pada sudut $2 \theta$ sekitar 29,76; 27,92; 23,00. Hasil ini dibandingkan dengan difraktogram zeolit jenis mordenite standar pada Gambar 4.2. Mordenit standar mempunyai intensitas tinggi pada sudut $2 \theta$ yaitu 27,$00 ; 25,63 ; 23,00$ dari perbandingan ini dimana bahan baku zeolit alam yang diperoleh dari Kabupaten Tapanuli Utara mendekati zeolit jenis mordenit ( $\mathrm{Na}_{8}\left(\mathrm{Si}_{4} \mathrm{Oal}_{8} \mathrm{O}_{96}\right) \cdot 24 \mathrm{H}_{2} \mathrm{O}$. Namun terdapat puncak-puncak (peak) dengan intensitas peak internal (counts) yang cukup tinggi muncul pada 
spektrum XRD dari zeolit alam Sarulla yang tidak dimiliki oleh mordenit seperti pada sudut 29,76 yang menunjukkan bahwa kristalinitas yang terbentuk pada zeolit alam Sarulla ini tidak hanya berstruktur mordenit tetapi ada kemungkinan tercampur dengan jenis klinoptilolit $\left(\left(\mathrm{K}_{2}, \mathrm{Na} 2, \mathrm{Ca}\right)_{3}\left[\mathrm{Al}_{6} \mathrm{Si}_{30} \mathrm{O}_{72}\right] \cdot 20 \mathrm{H}_{2} \mathrm{O}\right)$ serta beberapa senyawa impuritis. Sudut difraksi pada Gambar 4.1 yaitu $5 \geq 2 \theta \geq 42$ untuk melihat komposisi logam yang ada pada sampel bahan uji. Zeolit dihancurkan hingga berukuran 200 mesh atau 74 mikron.

\section{Proses Penjernihan Air}

Proses penjernihan air diperlihatkan dan dibahas seperti pada gambar dan pembahasan di bawah ini.

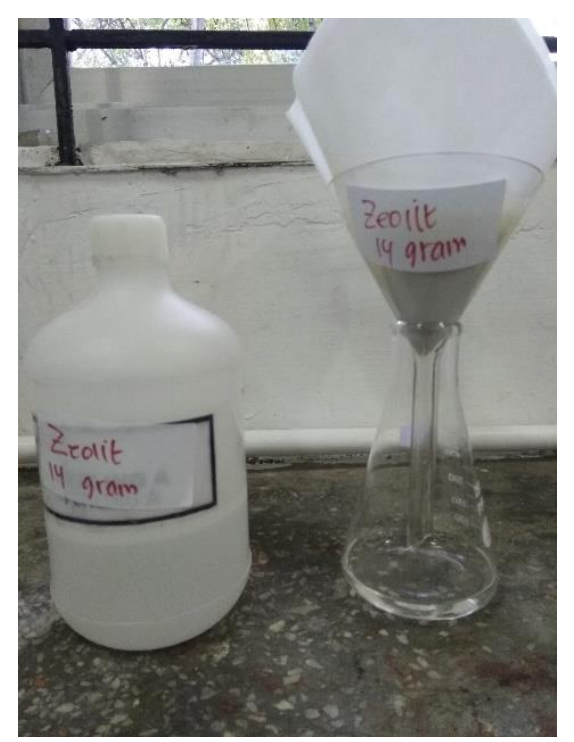

Gambar 4.3 Penjernihan/ penyerapan warna air sampel

Penggunaaan zeolit untuk menjernihkan air adalah karena zeolit berfungsi sebagai bleaching earth. Zeolit dapat menyerap warna pada sampel air. Di sini terjadi proses pertukaran ion atau penangkapan kation pada rongga-rongga kosong yang ada pada zeolit. Zeolit yang banyak memiliki senyawa oksida logam akan menyerap kation dan anion sehingga membentuk senyawa garam.

Berikut ini ditampilkan hasil analisa air dari beberapa variasi sampel. Pada tabel terlihat bahwa ada perbedaan jumlah kandungan logam $\mathrm{Fe}, \mathrm{Mn}$, dan $\mathrm{Cu}$ pada sampel seperti pada tabel 4.1 di bawah ini.

Tabel 4.1 Analisa Air

\begin{tabular}{|l|l|l|lr|lr|}
\hline No & $\begin{array}{l}\text { Nama } \\
\text { Sampel }\end{array}$ & $\begin{array}{l}\text { Jlh } \\
(\mathrm{mg} / \mathrm{L})\end{array}$ & $\begin{array}{l}\text { Jlh } \\
(\mathrm{mg} / \mathrm{L})\end{array}$ & $\begin{array}{l}\text { Jlh Cu } \\
(\mathrm{mg} / \mathrm{L})\end{array}$ \\
\hline 1 & Air sungai & 1,523 & 0,283 & $<0,008$ \\
\hline
\end{tabular}




\begin{tabular}{|l|l|r|r|r|}
\hline 2 & AZ 2 & $<0,030$ & 0,137 & 0,023 \\
\hline 3 & AZ 8 & 0,089 & 0,032 & 0,072 \\
\hline 4 & AZ 14 & 0,288 & 0,068 & 0,081 \\
\hline
\end{tabular}

Keterangan:

AZ 2 adalah air sungai dengan penyaringan zeolit 2 gram.

Sampel tersebut di atas dianalisa secara kualitatif. Hal ini dilakukan sebelum dan sesudah perlakuan penyerapan dan penjernihan. Hasilnya dapat dilihat ada perbedaan jumlah impuritis yang dapat dikurangi dari proses penyerapan dan penjernihan tersebut. Pada hasil analisa air pada tabel 4.1 diperlihatkan bahwa air sungai dengan penyaringan menggunakan zeolit cendrung memiliki kandungan logam meningkat. Hal ini disebabkan butiran halus zeolit masih tercampur dalam air sampel. Zeolit banyak mengandung oksida logam dan ikut teranalisa bersama dengan air sampel. Namun jika dilihat dari warna sampel air maka sampel sudah mengalami perubahan warna sehingga warna yang sudah diserap itu sudah menempel pada zeolit. Penelitian ini sudah berhasil menyerap warna sampel sehingga sampel menjadi lebih jernih secara kasat mata.

\section{KESIMPULAN}

1. Diperoleh serbuk zeolit dari zeolit alam Sarulla sebagai adsorben.

2. Diperoleh hasil uji ukuran partikel zeolit yaitu 200 mesh atau 74 mikron, analisa air yang optimal adalah pada penggunan zeolit 8 gram.

\section{SARAN}

Hasil dari penelitian dapat digunakan dan perlu dikaji lebih lanjut untuk mengurangi biaya.

\section{DAFTAR PUSTAKA}

[1] Aini, M.N., dan Indriati, L., (2007), "Proses Pemutihan Zeolit sebagai Bahan Pengisi Kertas", Buletin, Balai Besar Pulp dan Kertas, Bandung.

[2] Coed, M.A, (1991), "Kimia Polimer", Bandung: Institut Teknologi Bandung.

[3] Fengel, D., dan Wegener, G., (1995), "Kayu: Kimia, Ultrastruktur, Reaksi Reaksi”, Buku Teks, Gajah Mada University Press, Yogyakarta.

[4] Hanafi, I., Halimatuddahliana, dan Hazizan, (2005), "Properties of Polypropylene/Ethylene-Propylene Diene Terpolymer/Natural Rubber (Pp/Epdm/Nr) Ternary Blend: The Effect of Dynamic Vulcanization", Solid State Science and Technology, Vol.13, No.1 \& 2.

[5] Harahap, S, (2006), "Kajian Bahan Laporan Akhir, Badan Penelitian dan Pengembangan Propinsi Sumatera Utara, Medan.

[6] Ismail, H, and Suryadiansyah, R, (2004), "Effects of Filler on Properties of 
[7] Kohls, J. J., and Beaucage, (2002), "Rational Desing of Reinforced Rubber", Cur OP. Solid St Mat Sci., 6:183-194.

[8] Mc.Bain, J.W, (1932), "The Sorption of Gases and Vapors by Solids", Chapter 5, Rutledge and Sons, London.

[9] Mozgawa, W, Krol, M, and Barczyk, K, (2011), “ FT-IR Studies of Zeolites from Different Structural Groups, Faculty of Materials Science and Ceramics, AGH University of Science and Technology, Kraków, Please cite as: CHEMIK, 65, 7, 667-674

[10] Samir, M. A. S. A., F. Alloin, J. Sanchez and A. Dufresne. (2004), "CrossLinked Nanocomposite Polymer ElectrolytesReinforced With Cellulose Whiskers", Macromolecules. 37:4839-4844.

[11] Yu, L, (2009), "Biodegradable Polymer Blends and Composites from Renewable Resources", Canada: John wiley and Sons.

[12] Zhai,L.L, Ling, G.P, and Wang, Y.W, (2007), "Effect of nano-Al203 on adhesion strength of epoxy adhesive and Steel", College of Materials Science and Chemical Engineering, Zhejiang University, Hangzhou 310027, People's Republic of China, International Journal of Adhesion \& Adhesives 28: 23-28. 